\title{
Introduction: European administrative law - a thematic approach
}

\author{
Carol Harlow, Giacinto della Cananea and Päivi \\ Leino
}

\section{ABOUT THE HANDBOOK}

This Research Handbook is one of a series initiated by Edward Elgar and designed by them for 'scholars in European law', more particularly perhaps for young scholars looking for an area for useful and profitable research. The publishers identify a second potential readership of 'practitioners and policy-makers who wish to engage with the latest thinking and ongoing debates in the field' and who are not necessarily lawyers. Thus the Handbook is aimed not only at readers who are already knowledgeable about EU law in general and administrative law in particular but also at a wider readership interested in learning something about the governance structures of the EU and how it is administered. For this varied readership the contributors have been asked to combine 'a substantive analysis of the law' with 'a comprehensive analysis of the latest thinking, research and practice' in fields of EU administrative law that are topically of interest or in the process of rapid evolution. The Handbook is intended, in other words, to act as a guide to "what we know, don't know and ought to know' about EU administrative law. This we have tried to do.

It has not been an easy assignment. First and foremost the EU governance system inside which administrative law has to operate is distinctive and complex. Herwig Hofmann provides an overview of this in Chapter 1. Secondly, the definition of administrative law - in other words, what scholars think worthy of a place in the basket of administrative law - has expanded exponentially. We explain why this is so in Section 2. In addition, academic lawyers have begun to look more regularly outside the traditional boundaries of their subject to encompass the contribution of neighbouring social sciences. We have seen a rise in inter-disciplinary research and record with pleasure that socio-legal scholars now make a useful contribution. This cross-disciplinary body of theoretical and empirical work has greatly enriched the study of EU law; 


\section{Research handbook on EU administrative law}

indeed, the inter-disciplinary approach can be seen as a major contribution both to EU studies and to academic research more generally. We have naturally wanted to see it represented in this Handbook.

The Handbook is not designed to be exhaustive. We have tried primarily to provide pointers to areas of EU administrative law that are in the course of, or in urgent need of, development and further research. In so doing, we have adopted a thematic approach. We have selected for special attention in this Handbook: the role for administrative law in areas of authoritarian governance (see Section 3 below); the control functions of administrative law and the machinery for accountability, generally seen as the central objectives of contemporary administrative law (see Section 4); and the seemingly insoluble question of citizen 'voice' and access to policy-making at the European level of the EU (see Section 5). Finally, we look briefly in the concluding chapters at the influence of EU administrative law, both inside its borders and externally (see Section 6).

\section{THE 'EUROPEAN ADMINISTRATIVE SPACE'}

The 'European administrative space', or terrain on which EU administrative law operates, has very changeable boundaries. Community administration was originally conceived in terms of a two-level organization: at the European level Community law was implemented by the Commission; at national level it was implemented by the Member States. Under the principle of procedural autonomy, Member States were in charge of their own administrative systems and (subject to certain limitations), national law governed administrative and judicial procedure. Described as 'direct' when carried out at European level and 'indirect' when executed by national administrations, administration was in fact 'mixed' or 'shared' - a relatively simple structure with semi-federal characteristics. Since the first enlargement in 1971, however, when Ireland, the United Kingdom and Denmark acceded to the Communities, a stream of new members has joined, taking the total to 28 Member States and adding exponentially to its geographical and cultural terrain. Given the different administrative traditions and administrative law systems, the last point is important.

Alongside, there has been a steady upward flow of new competences to the Union. At least since the Maastricht Treaty in 1992, the tentacles of the EU have stretched ever more widely into previously sacrosanct areas of national competence, a development that presents challenges to 
over-stretched administrators and may sometimes be resented. EU expansion has not been a one-way process, however. It has been accompanied by - and perhaps necessitates - a process of fragmentation in which administration is no longer merely a split-level responsibility shared between the Union and Member States. The EU has followed global trends to devolved and disaggregated governance. Administration has become a composite process shared in random fashion between public authorities at national and transnational levels, in which private actors also play a part. A raft of semi-autonomous EU agencies are coming into being, which are rapidly gaining regulatory powers. ${ }^{1}$ The process of fragmentation is accentuated by increasing resort to relationships between groups of states that operate within the framework of the Union and may draw upon its institutions and machinery but do not involve all Member States. We meet, for example, in Elspeth Guild's account of the common European asylum system the Schengen Agreement dealing with border control and the Dublin I and II Conventions concerning asylum law (Chapter 6), while Michelle Everson and Christian Joerges discuss the asymmetrical post-crisis arrangements in the Eurozone in Chapter 7.

This ongoing process, which reflects both a general trend to globalization and a tendency within domestic systems, is further explicated in Chapter 1, where Herwig Hofmann gives a brief account of the stages by which the EU administration has evolved and the reasons for its untidy development with some explanations of the present-day governance forms. It is due to the diffuse and plural nature of EU administration, Hofmann suggests, that the emphasis of its administrative law is on cooperation, monitoring and information exchange. The EU system of administrative law is, in other words, less a 'command-and-control' system than one oriented towards integration. The theme is taken up later by Jens-Peter Schneider in a discussion of the implications of information technology for administrative law (Chapter 4).

\section{DELINEATING ADMINISTRATIVE LAW}

Two rather different conceptions of the functions of administrative law, both rooted in nineteenth-century visions of the state and its functions, ${ }^{2}$

\footnotetext{
1 See the study of the new financial agencies in Chapter 9.

2 See B Sordi, 'Révolution, Rechtsstaat, and the Rule of Law: Historical Reflections on the Emergence of Administrative Law in Europe' in S RoseAckerman and P Lindseth (eds), Comparative Administrative Law (Edward Elgar 2010).
} 
came to dominate administrative law theory during the course of the twentieth century. In the first model, the state is viewed as essentially coercive so that the primary function of administrative law becomes, in the colourful metaphor of an English author, to prevent 'the powerful engines of authority' from 'running amok'. 'Command-and-control' or 'rights-oriented' theory of this type is often court-oriented; it focuses, in other words, on the constitutional function of courts as the primary machinery for control (in modern terminology, accountability) of the executive. This is in many ways the starting point for EU administrative law. Jürgen Schwarze ${ }^{4}$ took the German doctrinal tradition into the first full-length survey of Community administrative law. His magnum opus, structured around five general principles presented as largely judicial constructs that have 'mostly been elaborated by the court itself' is unashamedly court-centred. ${ }^{5}$ Although he would later overtly acknowledge 'a double set of sources', adding primary and secondary law to the 'general principles or interpretative standards in the exercise of its jurisdiction by the European Court of Justice', Schwarze repeatedly underlines the Court's central role in the development of European administrative law. This is a stance he has always maintained. ${ }^{6}$

Alternative definitions of administrative law focus less on control and take a more positive view of the state as a collectivity where power is used not so much to 'impose the will of government upon society, but rather to enable the society itself to realize its collective goals'.7 Essentially instrumentalist and administration-centred, such theories accept the exercise of administrative power for policy purposes. From this perspective, the function of administrative law becomes to 'determine the organisation, powers and duties of administrative authorities' and provide 'the technical devices which are necessary to make the

\footnotetext{
3 HWR Wade, Administrative Law (Clarendon Press 1961) 1.

4 J Schwarze, Europäisches Verwaltungsrecht (Nomos 1988), translated as European Administrative Law (Sweet and Maxwell 1992).

5 J Schwarze, 'Developing Principles of European Administrative Law' [1993] PL 229, 230-31.

6 See the updated European Administrative Law (Sweet and Maxwell 2006) at ccxxvii-viii.

7 S Cassese, "Le droit tout puissant et unique de la sociétê": Paradoxes of Administrative Law' (2010) 22 ERPL 171, 176. The idea of the state as a collectivity or public service, which remains very influential in French public law, is associated with the work of Léon Duguit: notably, L'État les gouvernants et les agents (Fontemoing 1903) and Les transformations du droit public (Armand Colin 1913).
} 
policy efficient and to provide justice for individuals' ${ }^{8}$ Contemporary conceptions of administrative law would undoubtedly be less polarized. It is generally accepted today that administrative law involves a balancing function in which public (or collective) interests are weighed against private interests and that it inevitably oscillates between its positive and negative functions. Where the balance is to be struck may of course differ at different times, in different situations and in different systems. Stefan Kadelbach, for example, contrasts the administration-based French system with German administrative law, which he sees as rights-based and centred on judicial protection of the individual. There is support for this approach in the German proportionality principle, which has become a central tenet of EU administrative law. John Bell similarly contrasts the state-centred French system, which evolved inside the administration and tends necessarily to be more concerned with the legality of the administrative process, with rights-oriented, common law systems of judicial review, ${ }^{9}$ represented in the EU by the UK and Ireland. These nuances are important in EU administrative law, where the diverse traditions of the six founding Member States feed into the embryonic processes and procedures of the European Communities.

In general, the editors lean towards a positive and generous definition of administrative law as 'all the law that concerns administration' or 'the administration and the law applicable to it'. ${ }^{10}$ The problems for this Handbook of an approach that points towards self-standing case studies in regulatory administrative law for every area of administrative activity are, however, fairly obvious. ${ }^{11}$ We have necessarily had to be selective. In Chapter 6, for example, Elspeth Guild uses a case study in the conventional sense to cast light on the problems likely to arise in harmonizing the disparate administrative procedures of 28 Member States. Guild describes the initial negotiations in the politically sensitive area of asylum as 'rather tortuous' and the experience of implementing the

8 Definitions borrowed from the work of WI Jennings: see The Law and the Constitution (5th edn, Athlone Press 1967) 194. H Hofmann, G Rowe and A Türk, Administrative Law and Policy in the European Union (OUP 2011) adopt a similar position with respect to EU administrative law.

$9 \mathrm{~J}$ Bell, 'Mechanisms for Cross-fertilisation of Administrative Law in Europe' in J Beatson and T Tridimas (eds), New Directions in European Public Law (Hart Publishing 1998).

10 C Debbasch, Institutions et droits administratifs (PUF 1976); C Eisenmann, Cours de droit administratif (LGDJ 1982) vol 1, 17.

11 For just such a sectoral account of EU administrative law, see M Chiti and G Greco (eds), Trattato di Diritto Amministrativo Europeo (Giuffrè 1997, 2nd edn, 2007, vol II). 
resultant directives as more so. Her study 'unmasks the way that procedural rules are used to shortcut full and fair procedures for refugees and beneficiaries of international protection'.

A study from inside administration comes from Jonas Grimheden, Morton Kjaerum and Gabriel Toggenburg, who in Chapter 5 chart the work of the EU Agency for Fundamental Rights (FRA) over the past eight years. Legal frameworks, the authors conclude, leave a 'vast space' for completion at the administrative level; they need to be 'complemented and populated by data collection, analysis, comparative assessments, promotional activities, awareness raising and the like'. Only effective oversight of administrative practice can assure the protection of human rights. The authors see oversight as a regulatory function needing the attention of regulators; it cannot simply be left in the hands of courts. Jens-Peter Schneider in a formative chapter on information exchange pilots a development that administrative lawyers cannot afford to ignore. He identifies four categories of information exchange: 'upon request' practices and procedures; structured cooperation mechanisms; spontaneous exchanges without prior request; and shared databases. Schneider views these arrangements as a major component of composite administration in the EU and one which opens up an important new research area for administrative lawyers (Chapter 4).

\section{AUTHORITARIANISM AND ADMINISTRATIVE LAW}

In a recent article, Sabino Cassese has provided a valuable reminder of the origins of administrative law as the machinery used for purposes of public power (imperium or puissance publique) and thus an 'instrument of power and administrative supremacy'. ${ }^{12}$ We take this reminder very seriously. We have devoted much space to the authoritarian paradigm in the EU, which many writers see as in a constant process of regression from the Treaty commitment to the rule of law and democracy towards a state of executive government. Giacinto della Cananea directly confronts the nature of power and authority in the EU at the theoretical level in Chapter 2, probing the EU governance system from the perspective of a legal historian. He uses the lens of classical legal theory and the contrasting concepts of the right of executive command (imperium) and authority based on control and ownership (dominium) to analyse the legal

12 Cassese (n 7) at 176. 
arrangements that underpin EU public authorities and the new trends concerning inspecting powers and administrative procedures.

Updating this study to take on board the new economic powers developing in the area of the Eurozone, Michelle Everson and Christian Joerges provide a study in Chapter 7 of the so-called 'Fiscal Compact'. ${ }^{13}$ They deplore the impact on the legitimacy of the European project of 'a host of violations' in this area of the primary principles of the European legal order. The authors are pessimistic; they see 'very little hope indeed for the development of a form of administrative law which might overcome the challenges posed to the legitimate nature of constitutional government in and throughout Europe.'

Staying with the authoritarian theme, Vigjilenca Abazi and Deirdre Curtin in Chapter 8 highlight the growth of a 'secret state' as the EU gains a stronger foothold in areas of defence and security. They shine a spotlight on rules and administrative practices that govern access to information and criticize the way in which the EU institutions manipulate their institutional privileges of access to information as a source of power. The authors consider the democratic implications of executive secrecy in the EU with special reference to the impact on control over policy-making by the European Parliament. Päivi Leino is equally pessimistic in her study of the triad of EU agencies set in place to regulate and supervise national financial institutions (Chapter 9). She concludes that they also 'suffer from many of the general challenges of European administrative law and agencies', namely broad executive discretion, on the one hand, and lack of accountability, on the other. Her chapter ends this section, in which the authors are mainly pessimistic about an area of growing executive dominance that has largely escaped the controls of public law. It also opens the way to a discussion of administrative law's control function by providing a detailed account of the machinery in place to provide, at least theoretically, for accountability of the new financial agencies.

\section{ACCOUNTABILITY AND CONTROL}

The editors acknowledge administrative law's necessary control function and the significant role played by courts. We have, however, tried in this Handbook to interpret the concept of control more inclusively and extend the bounds of our subject to take in non-legal machinery for control and accountability. In Chapter 10, Tanja Börzel and Eva Heidbreder open our

13 The Treaty on Stability, Co-ordination and Governance in the Economic and Monetary Union of 2 March 2012 (TSCG). 
section on control with a theoretical discussion of the notion of compliance. They draw on research in the field of international relations to look at the administrative and legal mechanisms available at Union level for enforcement of EU law in the absence of a strong centralized coercive power. They then 'turn the international relations perspective on its head' by drawing on 'bottom-up implementation research' in the field of public administration and policy analysis to argue that local actors and their preferences need to be accommodated in the policy process. In Chapter 11, Colin Scott and Imelda Maher consider the centrality of regulatory techniques to oversight and accountability, relating regulatory theory to administrative law. The authors identify four 'meta-doctrines of regulatory accountability' that have emerged in response to the challenges associated with regulatory governance and become embedded in a range of sources including legislation and 'soft law'. ${ }^{14}$ Drawing together the underlying principles, they discuss ways of embedding these metadoctrines of accountability through the institutions and structures of EU administrative law, exploring in particular the concept of the Ombudsman (EO) as regulator exercising the control functions of administrative law.

In Chapter 12, Mariusz Baran returns us to the doctrinal standpoint of a lawyer with a detailed study of the jurisprudence of the two Luxembourg Courts. He focuses on a question of central importance to control theory, namely the intensity with which courts are prepared to review the administration. Baran draws attention to the variance in the standards applied by the Courts over the years as they have been called upon to pronounce on the performance of EU administrators. The starting point was a limited form of review based on 'manifest error' in the sense of a blatant or obvious mistake in the 'appreciation' of facts or law, a principle borrowed from French administrative law and justified by the CJEU on the ground of the 'wide measure of discretion' needed by the decision-maker when making complex economic assessments. In dealing with the highly technical scientific issues of risk assessment that increasingly make up the standard fare of the Commission's rule-making activities, the Court now has in its tool-kit the precautionary principle, a Treaty-based standard introduced to guarantee 'a high level of protection' in environmental cases. Recently, it has given itself permission to move

14 For the development and use of soft law in the EU context, see F Snyder, 'Soft Law and Institutional Practice in the European Community' in S Martin (ed), The Construction of Europe, Essays in Honour of Emile Noël (Kluwer International 1994); O Ştefan, 'European Union Soft Law: New Developments Concerning the Divide between Legally Binding Force and Legal Effects' (2012) 75 MLR 879. 
in some human rights cases to 'full' or even 'full and rigorous review'. Baran concludes, however, that the picture is generally one of judicial restraint. The stance adopted by the CJEU has been to allow the Commission to enjoy a broad scope of discretion, limiting review to situations where there has been a gross error of assessment or misuse of power or where the decision-maker has manifestly gone beyond the limits of its discretion.

Tapio Raunio turns in Chapter 13 to the role of parliaments in administrative law. He focuses on the scrutiny functions of the European Parliament (EP) and evaluates its success in securing accountability. He sees the EP as evolving from a mere 'talking shop' to emerge as a scrutineer of administrative behaviour determined to hold its co-legislator (the Council) and the Commission as EU executive to account. To achieve this goal, the EP has utilized its significant appointment, budgetary and legislative powers to good effect. In Chapter 14, Alex Brenninkmeijer discusses the essential audit powers of the European Court of Auditors (ECA). Describing EU administrative financial law as an amalgam of audit principles and procedures used previously in Member State audit systems, he traces the move in ECA audit from 'compliance audit' to the more modern technique of 'value-for-money audit' spreading through national systems. The tightening of these external audit powers has a triple value: at the first stage, they increase the likelihood of finding misconduct and error at a point in the chain when malfunction can be remedied; secondly, they enhance the supervisory powers of the Commission over EU public bodies and Member States; third, they greatly improve the chances of accountability to the EP by providing the latter with improved tools for their job. Brenninkmeijer calls also for greater cooperation between Member States and the Commission in financial matters to build an 'accountability network' 15 capable of holding financial administrators to account. This theme re-emerges in later chapters where Maartje de Visser describes the networking activities of European judges (Chapter 18) while Richard Rawlings highlights the work of the EO in constructing a European Network of Ombudsmen (Chapter 20).

\section{VOICE, CITIZENSHIP AND PROCESS}

If administrative law sets standards and defines the limits of public power, it also works on behalf of the citizen, governing relationships

15 See for explanation C Harlow and R Rawlings, 'Promoting Accountability in Multi-Level Governance: A Network Approach’ (2007) 13 ELJ 542. 
between the citizen and public authorities and providing machinery for citizen participation in public affairs. Citizens' rights are embedded in the foundational texts. The Preamble to the TEU commits the Union to respect the inviolable and inalienable rights of the human person, freedom, democracy, equality and the rule of law'. Article 10 of the Lisbon TEU provides that 'every citizen shall have the right to participate in the democratic life of the Union and that decisions shall be taken as openly and as closely as possible to the citizen'. Article 11 TEU underwrites this provision in several ways. It introduces the European Citizens' Initiative, a cumbersome procedure supposed to create a recognized space for citizen voice in EU law-making. More important, it commits the EU institutions to putting in place 'appropriate means [to] give citizens and representative associations the opportunity to make known and publicly exchange their views in all areas of Union action'. The institutions are to 'maintain an open, transparent and regular dialogue with representative associations and civil society' and the Commission 'shall carry out broad consultations'.

In Chapter 15, Joana Mendes examines the effectiveness of this provision in the context of executive rule-making, an important executive power exercised by the Commission and, increasingly, by EU agencies. Mendes contends that there is a misfit between the Treaty provisions on democracy (Articles 9 and 11 TEU) and the rule-making practices of the various administrative bodies. The Courts have shown little enthusiasm for the intensive 'hard look' review of Commission discretion once predicted by the American observer, Martin Shapiro. ${ }^{16}$ But as Ellen Vos has pointed out, when Commission rule-making in scientific or technological matters is in issue, courts are at a disadvantage; 'disputes on science-based measures not only involve legal questions but also touch upon the science underpinning the disputed measures. It is no secret that in such disputes, the European Union Courts ... visibly struggle in dealing with the technicalities of such cases'. The same could perhaps be said of the EP, which before the Lisbon Treaty had limited powers over implementing regulation, which was the prerogative of the expert Comitology. ${ }^{17}$ This left the external monitors of accountability to concentrate their efforts on procedure. It is then surprising to find the EP drawing back from procedural regulation of executive law-making by confining its

16 M Shapiro, 'The Giving Reasons Requirement' (1992) University of Chicago Legal Forum 179.

17 See for an historical account of Comitology, F Bergström, Comitology: Delegation of Powers in the European Union and the Committee System (OUP 2005). 
work on an overall codification of administrative procedure to individuated decision-making. ${ }^{18}$ Joana Mendes makes her viewpoint clear. She supports the ReNEUAL cause of formal, written procedures across the rule-making board. She further argues for a systematic consideration at a normative level of rule-making procedures, where the structuring and control functions of administrative procedure have never been adequately taken into consideration. The editors note that this is a field of study in which there is a particular need for empirical research and where the techniques of political science are especially valuable. We note with pleasure the growth of inter-disciplinary research in the area.

Citizen participation depends on openness and transparency, good governance values to which the EU has paid lip service but shown little commitment. There are numerous declarations from the EU institutions of the importance of transparency of the decision-making process in strengthening the democratic nature of the Union and confirming public confidence in the administration but Nordic Member States, which prize open government highly, have consistently struggled to reinforce freedom of information at Union level. A right of access to documents is now contained in Article 15 TFEU and Article 42 of the European Charter of Fundamental Rights (ECFR), implemented in procedural terms by an EU Regulation. ${ }^{19}$ Yet problems of access to information are persistent and surface in several Handbook chapters. In their study of the secret state, for example, Abazi and Curtin highlight the deleterious effects on democracy of unfettered executive control over information classified as sensitive by the executive. The authors are critical of the extent to which 'security actors' control the gathering and flow of information, in particular the lack of 'timely and full access' to information by parliaments and the uncertain and relatively weak control by the Luxembourg Courts (Chapter 8). In Chapter 16, Liisa Leppävirta and Helen Darbishire talk with practical experience of the problems in accessing information and examine the patchy record of the two Luxembourg Courts in protecting access rights. They point to serious gaps left by the current EU legislation that would require legislative intervention and to serious deficiencies at the administrative level. There is an endemic failure to keep adequate document registers; unwillingness to comply with and

18 See European Parliament Resolution of 15 January 2013 with recommendations to the Commission on a Law of Administrative Procedure of the European Union (2012/2024 (INL)).

19 Regulation (EC) No 1049/2001 of the European Parliament and of the Council of 30 May 2001 regarding public access to European Parliament, Council and Commission documents, OJ L145/43. 
occasional lack of compliance with decisions of the EO and CJEU. To summarize, the authors find an apparent disinclination on the part of the institutions to make citizen access to documents possible.

Articles 43, 44 and 47 ECFR enshrine further rights for the citizen in the area of administrative justice. They contain a right to complain to the $\mathrm{EO}$ or petition the EP and, in respect of any right or freedom guaranteed by the law of the Union, the right to a fair and public hearing within a reasonable time by, and effective remedy from, an independent and impartial tribunal previously established by law. There is, however, a self-congratulatory note to the assertion frequently heard in the CJEU to the effect that 'the Treaty has established a complete system of legal remedies and procedures designed to ensure judicial review of the legality of acts of the institutions, and has entrusted such review to the Community Courts'. ${ }^{20}$ Many a disappointed litigant, frustrated by the obstacles in the path of an 'effective remedy', would answer otherwise, citing multiple problems with access, delays, cost and the absence of effective remedies in courts that possess no mandatory remedies. Reviewing the apparent 'gap' in effective judicial protection in Chapter 17, Kieran Bradley is relatively sympathetic to the Court's notably restrictive position on standing to litigate in the CJEU. In contrast to much of the academic literature, Bradley sees the Court's reluctance 'simply to airbrush "individual concern" out of the picture' as partially justified by the increasing workload, delays and backlogs, catalogued in its annual reports. A more generous interpretation, he concludes, might undermine the whole system of review.

To fashion an 'accountability network' out of the complex two-tier structure of national and Union Courts is, however, no easy task as Maartje de Visser demonstrates in Chapter 18. De Visser provides an account of the modalities through which judicial collaboration is achieved. In contrast to more conventional accounts, which focus on the preliminary reference procedure prescribed in Article 267 TFEU as the formal channel for judicial contact in the EU judicial arena, de Visser looks at the opportunities for extra-judicial networking in the many arenas, such as professional associations and conferences, where judges meet informally. Encouraging further empirical research into an activity that she believes will continue, de Visser includes advice for young researchers. The phenomenon is an intricate one, and if due consideration is to be given to the experiences of judges and court personnel who in practice

20 E.g. in Case C-50/00 Unión de Pequeños Agricultores $v$ Council EU:2002:462, [40]. 
operate the channels of judicial communication, an interdisciplinary approach and expertise will be helpful.

In this respect, Laura Muzi's contribution to this Handbook (Chapter 19) serves several purposes. It is partly a doctrinal analysis of the recent case law on the widely recognized due process right embedded in Article 47 ECFR and already strongly protected by the CJEU. Article 41 ECFR takes this right to the administrative level, providing for an individual's right to a hearing before any individual measure which would affect someone adversely is taken by the administration. Unusually, however, Muzi bases her analysis on a statistical study of the recent cases drawing attention to the paucity of statistical or empirical research in the vast literature on the CJEU, much of it written by social scientists. ${ }^{21}$ We have little concrete information as to who the litigants are 22 and still less about their experience of litigation. The Annual Reports of the CJEU contain bare statistics and a dataset based on these figures and compiled by Alec Stone Sweet and Thomas Brunell in $2008^{23}$ does little more than list institutions or Member States and the legal subject matter of 11,973 separate claims. Indeed, expressing disquiet over the insufficiency of the statistical data on which his own research was based, the author of a study of enforcement procedure recently drew attention to the dearth of statistical studies of the Court of Justice. He called for better data sources and urged scholars to invest more energy in collecting data. ${ }^{24}$ Again, a recent article on judicial preference based on a statistical study of cases decided by various Chambers also draws attention to the paucity of empirical work. ${ }^{25}$ We know little about judges, their personalities, backgrounds and preferences. ${ }^{26}$ Theoretical analysis based on statistical

21 It is tabulated by A Stone Sweet, The European Court of Justice and the Judicialization of EU Governance (2010) 5 Yale online living reviews in EU governance No 2/2010.

22 See for an early attempt, C Harding, 'Who goes to Court in Europe? An Analysis of Litigation against the European Community' (1992) 17 EL Rev 105.

23 'The European Court and Actions for Annulment: Data Set on Actions under Article 230, 1954-2006' (2008) is openly available for further research at www.eu-newgov.org EUI, but has not been updated.

$24 \mathrm{O}$ Treib, Implementing and complying with EU governance outputs (2014) 9 Yale online living reviews in EU governance No 1/2014.

25 D Kelemen and M Malecki 'Do ECJ Judges all Speak with the Same Voice? Evidence of Divergent Preferences from the Judgments of Chambers' (2012) 19 JEPP 59.

26 H Schepel and R Wesseling, 'The Legal Community: Judges, Lawyers, Officials and Clerks in the Writing of Europe' (1997) 3 ELJ 165. And see now A Vauchez and B de Witte (eds), Lawyering Europe (Hart Publishing 2013). 
data is also rare. ${ }^{27} \mathrm{We}$ are glad to see some fresh green shoots emerging 28 but, if this Handbook is designed to highlight what we don't know and ought to know about administrative law, there is much work to be done in this area.

There is an emphasis in several of these chapters on the balance in between classical control functions of administrative law and its function in providing machinery to regulate and facilitate citizen/state relationships. Thus both Mendes and Muzi point to the need for a clear set of procedural rules to set standards against which public authorities can be held accountable. In Chapter 20, however, Richard Rawlings concludes this section by introducing a very different theme. He argues for a new look at the way disputes are handled by the Union administration and the purposes that complaints procedures can serve. Treating the Commission's SOLVIT and PILOT services as prototypes, he maintains that an effective complaints service serves a dual function: it should provide redress to individual complainants while at the same time allowing citizens to voice their disquiet over unsatisfactory policies and informing the administration about areas of inferior quality. He points too to the changing role of the EO in handling complaints. All three European Ombudsmen have used their office to work towards greater freedom of information in the EU but Rawlings sees a new departure in the use made by the present Ombudsman, Emily O'Reilly, of her power of Own Initiative Investigation to search proactively for and give voice to citizen opinion. This lends the office of Ombudsman a new political role.

\section{IMPACT AND OUTREACH}

EU administrative law is very much a compound and plural system in which the administrative law of the Union co-exists with and draws heavily on the national administrative law of the 28 Member States. In the early days of association, the Communities were naturally imitators. As is well-known, the procedures and principles of the ECJ were largely borrowed from France as were the grounds for judicial review - lack of competence, infringement of an essential procedural requirement, infringement of the Treaties or of any rule of law relating to their application, or misuse of powers - which were entrenched in what is now

27 But see T Tridimas and G Tridimas, 'National Courts and the European Court of Justice: A Public Choice Analysis of the Preliminary Reference Procedure' (2004) 24(2) International Review of Law and Economics 125.

28 A Vauchez and B de Witte (n 26). 
Article 263 TFEU (ex Art 230 TEC). The influential office of European Ombudsman on the other hand is borrowed directly from the Nordic countries and it was to Nordic precedents that Jacob Söderman, previously the Finnish Ombudsman who was the first holder of the office, based his comportment. ${ }^{29}$ Again, much of the early administrative law jurisprudence of the CJEU is founded on 'the common principles of the Member States' as referenced in Article 288 TEC, which provides for non-contractual liability. It is common knowledge too that the celebrated European proportionality principle has German origins ${ }^{30}$ and AngloAmerican principles strongly influenced the evolution of due process rights in EU administrative proceedings. ${ }^{31}$

The EU is not solely an importer, however; it is also a vigorous exporter. Indeed, Stefan Kadelbach sees EU administrative law as composed of three distinct bodies of law: the rules and principles governing the execution of EU law by the institutions of the Union and in Member States whenever it is directly effective; the rules and procedures used by national authorities in the enforcement of EU law; and situations where national systems are indirectly influenced by EU law. The first represents for Kadelbach 'the genuine law of the Union' 32 and it is on this body of law that this Handbook has for the most part concentrated. The so-called 'spill over effect' on the other hand is a dimension of our subject that falls outside the ambit of this Handbook. We have to draw the line somewhere and, as Matthias Ruffert reminds us in his discussion of the state of scholarship in EU administrative law (Chapter 3 ), there are substantial linguistic obstacles to dialogue and understanding between comparative administrative lawyers, highly desirable though it may be.

29 P Leino, 'The Wind is in the North - The First European Ombudsman (1995-2003)' (2004) 10 EPL 333; P Bonnor, 'Ombudsmen and the Development of Public Law' (2003) 9 EPL 237.

30 See Case 11/70 Internationale Handellgesellschaft $v$ Einfuhr- und Vorratsstelle Gertreide EU:C:1970:114. And see E Emiliou, The Principle of Proportionality in European Law: A Comparative Study (Kluwer Law International 1996).

31 Case 17/74 Transocean Marine Paint v Commission EU:C:1974:106; F Bignami, 'Three Generations of Participation Rights before the European Commission' (2004) 68 Law and Contemporary Problems 61.

32 S Kadelbach, 'European Administrative Law and the Law of a Europeanized Administration' in C Joerges and R Dehousse (eds), Good Governance in Europe's Integrated Market (OUP 2002) 167-68. See similarly M Ruffert, 'Droit de l'intégration européenne et droit administratif' in P Gonod, F Melleray, P Yolka (eds), Traité de Droit Administratif (Dalloz 2011) vol 1, 734-37. 
Implementation is not, as Börzel and Heidbreder remind us in Chapter 10, a process confined to the administration and supervised solely by the national courts. This is, however, a Handbook on Administrative Law and it is on this aspect of implementation that we have chosen to focus. In Chapter 21, Nina Półtorak documents a single sustained and substantial example of Europeanization that we regard as especially important: the very substantial impact of EU law on candidate states for membership of the EU around and after the time of their accession. A greater input from scholars in the newer Member States in Eastern Europe would be particularly welcome in this important area of research.

Półtorak contributes a knowledgeable and detailed study of Poland as the exemplar for the impact of EU law on a pre-existing and developed national administrative law system, already undergoing a process of considerable reform. Adjustment is seen to involve a sizeable input of training and restructuring of highly variable administrations and administrative law systems. The Półtorak contribution fills a significant gap in the literature and makes available to Anglophone readers important material that is otherwise only available in Polish. Yet politics cannot be entirely excluded. The election of a new government in Poland opened up a dispute over nominations to the Polish Constitutional Tribunal, which brought threats of a potentially-punitive process by the Commission under its Rule of Law Framework monitoring procedure. ${ }^{33}$

As increasingly the EU plays a leading role on the world stage and signs up in its own name to treaties and conventions, a wider range of relationships is developing. An internal, two-way exchange is starting to be replaced by triangular and multi-level import/export processes. These create greater space to be filled by imports and exports and more scope for cross-fertilization. The EU worked with the United Nations Economic Commission for Europe (UNECE), as Edoardo Chiti reminds us in Chapter 22, to promote the Aarhus Convention and contributed to the text. EU agencies work and exchange ideas with international institutions and agencies. Europol has powers, for example, to sign agreements with other agencies or third countries. Chiti is generally optimistic. He believes in the capacity of the EU legislator to produce sound implementing laws and of the administration to produce balanced and workable administrative practices. And the $\mathrm{EU}$ is no mere plagiarist; it is a

33 Commission Communication, 'A new EU Framework to strengthen the Rule of Law' COM (2014) 158 final. See also Council of Europe Venice Commission, Opinion on Amendments to the Act of 25 June 2015 on the Constitutional Tribunal of Poland, Opinion No 833/2015, CDL-AD (2016) 001. 
repository of ideas and practices that can offer much internationally. This developing area for EU administrative law opened up by Chiti is a subject to which we shall return in our final chapter. 
Carol Harlow, Giacinto della Cananea, and Päivi Leino - 9781784710682 Downloaded from PubFactory at 04/26/2023 11:44:39AM via free access 